\title{
"MENOS DIREITOS E EMPREGO OU TODOS OS DIREITOS E DESEMPREGO": A “UBERIZAÇÃO” DO TRABALHO NO BRASIL NO DISCURSO PRESIDENCIAL
}

\author{
JOÃO PAULO MARTINS DE ALMEIDA ${ }^{1}$
}

\author{
Programa de Pós-Graduação em Linguística e Literatura \\ Universidade Federal de Alagoas
}

Faculdade de Letras - Avenida Lourival Melo Mota - Tabuleiro dos Martins - 57083-

$$
410 \text { - Maceió - AL - Brasil }
$$

joao.paulo martins@hotmail.com

\begin{abstract}
Resumo: Neste trabalho, considerando as declarações de Jair Bolsonaro a respeito da situação dos/as trabalhadores/as no Brasil, são analisadas as formas como o discurso do mandatário reflete o discurso de mercado que promove o empreendedorismo e a "uberização" do mundo do trabalho, isto $e ́$, a desregulamentação de leis trabalhistas que tornam as ocupações laborais mais precárias. Tendo em conta as contribuições teóricas de Michel Pêcheux (2014) a respeito do processo discursivo, entendendo-o como inscrito numa relação de classes, intenta-se realizar a análise das condições de produção do discurso em consonância a Courtine (2016), que as compreende como as condições históricas que determinam a produção das materialidades discursivas. Dessa forma, procura-se demonstrar como o discurso de mercado, que rege a lógica de negócios da Uber, está se expandindo para vários setores da atividade laboral - no Brasil e no mundo.

Palavras-chave: discurso; neoliberalismo; "uberização"; empreendedorismo
\end{abstract}

\begin{abstract}
In this work, considering the statements made by Jair Bolsonaro on the situation of workers in Brazil, we try to analyze the ways in which his discourse reflects the discourse of the so-called market, one that promotes (self)entrepreneurship and the "uberisation" of the work world, that is, the deregulation of labor laws, hence making jobs increasingly precarious. Taking into account the theoretical contributions by Michel Pêcheux (2014) who considers the discourse process fit into a class relation, our intent is to analyze the conditions of production of the discourse in accordance to Courtine (2016), who understands them as the historical conditions which determine the production of the discoursive materialities. Thus, we intend to demonstrate how the discourse of the market, which orients the business model for companies such as Uber, keeps on expanding into several segments of the labor world - in Brazil and throughout.
\end{abstract}

\footnotetext{
1 Doutorando em Linguística pelo Programa de Pós-Graduação em Linguística e Literatura da Universidade Federal de Alagoas. Mestre e especialista em Linguística (PPGLL/UFAL). Licenciado em Letras/Português pela Centro Universitário Uniseb. Pesquisador do Grupo de Estudos em Análise do Discurso (GrAD/UFAL). http://lattes.cnpq.br/3499373178868293
} 
Keywords: discourse; neoliberalism; “uberisation”; entrepreunership.

\section{CONSIDERAÇÕES INICIAIS}

O presente artigo pretende analisar o discurso político-econômico do presidente Jair Bolsonaro, de seu vice, Hamilton Mourão, e de empresas como a Uber, discursos estes que pendem ao neoliberalismo ${ }^{2}$ e se inscrevem na formação ideológica do capital, entendida como antagônica à formação ideológica do trabalho, configurações estas que se inserem numa mesma conjuntura que organiza a sociedade, a saber, a Formação Social Capitalista (AMARAL, 2007). A partir da sequência discursiva de referência (SDr) "Menos direitos e emprego ou todos os direitos e desemprego", enunciado formulado pelo presidente Jair Bolsonaro em 2019, far-se-á um gesto interpretativo que remonta este dizer às condições de produção mais imediatas da conjuntura brasileira que permitiram a irrupção deste discurso, a partir de 2017, ano que inaugura o desmonte da Consolidação das Leis do Trabalho (CLT) pelo ex-presidente Michel Temer, projeto que continua hodiernamente com as sucessivas tentativas de aprofundamento da deterioração de direitos trabalhistas por parte do governo de Jair Bolsonaro. Faz-se, ademais, um gesto que analisa as raízes históricas da sociedade brasileira a partir das contribuições de Schwarcz e Starling (2015) e Ricardo Antunes (2018), mostrando como a falta de acesso à educação e a empregos são problemas ainda não completamente resolvidos e que levam à ocupação de postos de trabalho precarizados, heranças de uma sociedade marcada pelo patrimonialismo, pela hierarquia e pela insegurança social advindos do processo de colonização e de escravidão, o que se verifica pelo processo de naturalização da "uberização" do trabalho, isto é, processo que aumenta a exploração da força produtiva sem, no entanto, garantir-lhe direitos mínimos conquistados historicamente no século XX.

A "uberização" surge, assim, como um neologismo que serve à teoria crítica do neoliberalismo, ideário político-econômico que vem prevalecendo na experiência brasileira recente, aprofundado a partir da queda do governo Dilma Rousseff em 2016. "Uberização" é por nós compreendida como uma materialidade linguístico-discursiva que reflete o material da história: a partir do texto, remete-se ao discurso: do material da língua ("uberização"), chega-se ao discurso (o processo de luta de classes entre capitalistas e trabalhadores/as impresso, como efeitos de sentido, na superfície textual). Através desta materialidade, pode-se intentar compreender os efeitos de sentidos constituídos no processo discursivo, desvelando a opacidade da linguagem, ou seja,

\footnotetext{
$2 \mathrm{O}$ conjunto ideológico que se difundiu como neoliberalismo remonta às teses defendidas pelo economista austríaco F. Hayek (1899-1992). O neoliberalismo, releitura ainda mais conservadora do liberalismo do século XVII, preconiza um Estado mínimo por meio de privatizações de empresas estatais e de reformas que, na verdade, são contrarreformas, pois preveem a supressão ou a redução de direitos e garantias sociais que são obstáculos à reprodução do capital. Conforme Netto \& Braz (2012, pp. 238239): “A ideologia neoliberal, maciçamente generalizada pelos meios de comunicação social a partir dos anos oitenta do século passado, [...] legitima o projeto do capital monopolista de romper com as restrições sociopolíticas que limitam a sua liberdade de movimento. [...] o objetivo real do capital monopolista [no neoliberalismo] não é a 'diminuição' do Estado, mas a diminuição das funções estatais coesivas, precisamente aquelas que respondem à satisfação dos direitos sociais. Na verdade, ao proclamar a necessidade de um 'Estado mínimo', o que pretendem os monopólios e seus representantes nada mais é que um Estado mínimo para o trabalho e máximo para o capital”. Grifo dos autores.
} 
mediante a análise de "uberização", pode-se observar um processo em que se verifica a inserção dos trabalhadores/as no mundo do trabalho sem legislações que os/as beneficiem e lhes assegurem direitos básicos; verifica-se, pois, a sistemática deterioração de direitos dos/as trabalhadores/as brasileiros/as, iniciada com a reforma trabalhista de 2017, passando pela reforma da previdência em 2019 e que segue avançando como projeto de governo até o momento em que se escreve este artigo, com discussões governamentais que avaliam a manutenção do "teto de gastos", que limitam o orçamento público de investimento em saúde e educação, e novas reformas de cunho neoliberal, como a administrativa, que imporia limitações ao funcionalismo público.

Através do aparato teórico-analítico inaugurado por Michel Pêcheux (2014) para o estabelecimento da Análise do Discurso, bem como a partir das contribuições de JeanJacques Courtine (2016) e Eni Orlandi (2005), intenta-se mobilizar gestos de descrição e de interpretação de dizeres oriundos dos segmentos político e empresarial no Brasil que sustentam um discurso que privilegia o neoliberalismo, materializando, na linguagem, a reconfiguração nefasta do mundo do trabalho no Brasil pós-golpe de $2016^{3}$. Num país que atravessa profunda crise social, com cerca de 30 milhões de desempregados, subempregados e desalentados, o estabelecimento da Uber em 2014 e sua consolidação nos grandes centros urbanos brasileiros como "um dos maiores empregadores do país" ajudam a explicar o processo discursivo que engendra o sentido produzido em frases profundamente contraditórias, como a que dá título a este trabalho. A "uberização" pode ser compreendida, assim, como um processo hodierno do mundo do trabalho, em que o/a trabalhador/a precarizado/a precisa escolher entre ter "menos direitos e emprego" ou "todos os direitos e desemprego", conforme asseverado pelo presidente Bolsonaro.

\title{
DA TEORIA DO DISCURSO À "UBERIZAÇÃO”
}

\section{FORMAÇÃO IDEOLÓGICA, FORMAÇÃO DISCURSIVA, CORPUS E DISPOSITIVO DE ANÁLISE}

Entendemos o discurso em conformidade com Orlandi (2005), como um conjunto complexo de dizeres e de práticas sociais, sustentados em relações ideológicas perante o mundo. Segundo a autora:

\begin{abstract}
A Análise de Discurso, como seu próprio nome indica, não trata da língua, não trata da gramática, embora todas essas coisas lhe interessem. Ela trata do discurso. E a palavra discurso, etimologicamente, tem em si a ideia de curso, de percurso, de correr por, de movimento. O discurso é assim palavra em movimento, prática de linguagem: com o estudo do discurso, observa-se o homem falando. (ORLANDI, 1999, p. 13 - Grifo nosso)
\end{abstract}

\footnotetext{
${ }^{3}$ O golpe de 2016 se refere ao episódio que levou ao impeachment da ex-presidenta Dilma Rousseff a partir de um pretexto jurídico - as "pedaladas fiscais" -, uma manobra que não encontrou consenso entre os juristas e os políticos de que se trataria de crime de responsabilidade, conforme previsto pela Constituição Federal, não sendo, portanto, motivo sólido para um impeachment.
} 
O discurso, como visto, é prática social, cuja materialidade é a língua que, ao expressar, historicamente, a ideologia, engendra sentidos para as posições discursivas ocupadas pelos sujeitos que enunciam. Cabe perguntar, todavia: que sujeito discursivo é este? Qual sua posição e lugar no mundo? Em que tipo de sociedade habita esse sujeito? Certamente não estamos falando do mundo primitivo, tampouco do período medievo; já demos indícios de que nosso objeto se trata de um discurso inscrito no hodierno. Para o analisarmos, pois, é imprescindível que tratemos dessa contemporaneidade e analisemos como ela se estrutura socialmente: não estamos falando de um modo de produção escravista ou feudal, por exemplo. Estamos tratando de uma sociedade constituída de classes que tem como central a exploração do homem por outrem através da venda de sua força de trabalho, equiparada, portanto, à qualidade de mercadoria; uma sociedade em que, enquanto dissolve o valor de uso do trabalho, impõe o valor de troca e a maisvalia. Esta não é qualquer sociedade na história humana; esta é a sociedade resultante de processos históricos que, há aproximadamente 300 anos, vêm modificando o tecido social, as formas de relação e de produção humanas, através de revoluções na conquista de novos territórios, na organização das cidades, na cultura e na representação política. Estamos tratando de uma sociedade inscrita no modo de produção capitalista ${ }^{4}$.

Se o objeto aqui estudado é um discurso hodierno, para descrevê-lo importa falar do capitalismo, pois é esse o sistema que rege os homens no período histórico considerado. E, se ele os rege, no discurso - nos efeitos de sentido produzidos pelo discurso - encontraremos os alicerces ideológicos que refutam ou sustentam o próprio sistema capitalista, seus valores e suas práticas. As relações de força conflituosas existentes numa sociedade cujo motor é a luta de classes se manifestam nas formulações do sujeito - no que ele diz (o dito) - sobre a realidade que o circunda, em suas formações discursivas. O dito, contudo, revela não-ditos e mesmo o silenciado. Esse conjunto de dizeres e silêncios se estrutura nas condições históricas objetivas dos homens. Por isso, para fazermos uma análise discursiva, necessário é observar "as margens do dizer", pois elas "também fazem parte dele". (ORLANDI, 2005, p. 28)

Como no procedimento da Análise do Discurso "necessita-se compreender e explicar o 'conjunto complexo e contraditório' (o interdiscurso) das formações discursivas em jogo numa dada formação social sob a dominação do conjunto das formações ideológicas" (AMARAL, 2007, p. 24), passemos a tratar destes conceitos para situar melhor nosso objeto, seus dizeres e "as margens de seu dizer".

O Presidente da República, seu vice e empresas como a Uber ocupam uma posição de classe nesta sociedade sobre a qual viemos fazendo alusão. Particularmente em nosso caso, quando tratamos destes sujeitos analisados, fazemos referência a políticos que ocupam altos cargos, concentram poder e representam interesses de grandes grupos capitalistas, como empresas estrangeiras. Tais sujeitos dispõem de meios para facilitar as atividades das empresas e aumentar a exploração da força de trabalho, de forma que se garantam lucros aos empregadores, realizando, assim, práticas conformes ao capitalismo. O discurso político-econômico sobre o qual se trata, logo, é

\footnotetext{
4 “O modo de produção capitalista (...), que sucedeu, no Ocidente, o modo de produção feudal, é hoje dominante em escala mundial. Desde sua consolidação, na passagem do século XVIII ao XIX (...), impera na economia das sociedades mais desenvolvidas (centrais) e vigora na economia das sociedades menos desenvolvidas (periféricas). O MPC é dominante em todos os quadrantes do mundo, configurando-se como um sistema planetário, [fundado] na exploração do trabalho" (NETTO; BRAZ, 2012, pp. 108-109).
} 
atravessado pelos valores desta formação social, particularmente os valores de uma das posições de classe possíveis desta sociedade: os valores e as ideias capitalistas.

Por formação social, entende-se conforme Amaral (2007, p. 24), "um complexo histórico constituído pela imbricação de diversos modos de produção e reestruturadas em função da dominância de um dos modos de produção". Para Marx (2008, p. 47), tem-se, na sociedade capitalista, um modo de produção cuja força econômica está calcada no capital, constituindo a base material desta sociedade, a sua estrutura econômica, "a base real sobre a qual se eleva uma superestrutura jurídica e política e à qual correspondem formas sociais determinadas de consciência". Nas relações de produção da sociedade, portanto, observa-se a dominância do capital - e por formação social capitalista entendemos este complexo histórico em que tal dominância opera ${ }^{5}$.

Nas relações sociais postas pelas forças produtivas da sociedade que aqui se analisa, duas classes fundamentais emergem: "a que detém os meios de produção, inclusive a força de trabalho - os capitalistas - e a que vende a força de trabalho, os trabalhadores" (AMARAL, 2007, p. 24). Se falamos de sujeitos que dispõem dos meios para regulamentar a cadeia produtiva no Brasil - e que assim o fazem beneficiando os donos dos meios de produção, e não os trabalhadores -, é razoável que os identifiquemos como pertencentes ao primeiro grupo. Dessa forma, é preciso considerar a ideologia e o papel que ela tem em produzir mecanismos de sustentação que conservam as diferenças entre trabalhadores e capitalistas, "necessárias ao funcionamento das relações sociais de produção na sociedade de classe", uma vez que "a ideologia tem a função de 'mostrar' aos sujeitos da produção seu lugar no interior desta sociedade" (AMARAL, 2007, p. 25). No caso do discurso presidencial, ao enunciar que os trabalhadores precisam escolher entre ter "menos direitos e emprego ou todos os direitos e desemprego", percebe-se um alinhamento com a ideologia dominante, isto é, a ideologia da classe dominante, que busca simular evidências de opacidade da linguagem, mostrando, pelo dito, uma "verdade inquestionável", um consenso "lógico" das relações sociais que são fundadas, na verdade, no conflito, apagando-se o fato de que a escolha que sobra ao trabalhador não é algo natural, mas uma imposição dos capitalistas.

Em sua explicitação sobre os fundamentos de uma teoria materialista do discurso, Michel Pêcheux (2014) tratará das condições ideológicas da reprodução/transformação das relações de produção, considerando, tanto quanto a ideologia, as determinações econômicas que condicionam a reprodução/transformação destas relações, salientando que, ao assim fazê-lo, designa "o caráter intrinsecamente contraditório de todo modo de produção que se baseia numa divisão em classes, isto é, cujo "princípio' é a luta de classes" (p. 130). Se "a luta de classes atravessa o modo de produção em seu conjunto", inclusive naquilo que Althusser (1985) apontaria como os Aparelhos Ideológicos de Estado (a família, a Igreja, a escola etc.), todas as relações sociais são permeadas pelas contradições ideológicas e materiais das diferentes formações sociais. Mais adiante em sua formulação teórica, assevera Pêcheux:

\footnotetext{
5 “O capitalismo é a organização da sociedade na qual a terra, as fábricas, os instrumentos de produção etc. pertencem a um pequeno número de proprietários fundiários e capitalistas, enquanto a massa do povo não possui nenhuma ou quase nenhuma propriedade e, por isto, deve vender a sua força de trabalho" (LÊNIN apud NETTO;BRAZ, 2012, p.101).
} 
[...] em sua materialidade concreta, a instância ideológica existe sob a forma de formações ideológicas [...] que, ao mesmo tempo, possuem um caráter 'regional' e comportam posições de classe: os 'objetos' ideológicos são sempre fornecidos ao mesmo tempo que 'a maneira de se servir deles' - seu 'sentido', isto é, sua orientação, ou seja, seus interesses de classe ao quais eles servem -, o que se pode comentar dizendo que as ideologias práticas são práticas de classe (de luta de classes) na Ideologia. (2014, p. 132. Grifo nosso).

Pode-se concluir, assim, que as formações ideológicas não são apenas maneiras de interpretar o mundo, compostas estritamente de ideias, mas, antes, de fazeres, de práticas sociais, segundo a classe a que o sujeito pertence.

Conforme Pêcheux (2014, p. 135) assegura, "só há prática através de e sob uma ideologia", e mais adiante, "é a ideologia que, através do 'hábito' e do 'uso', está designando, ao mesmo tempo, o que é e o que deve ser [...], sob a 'transparência da linguagem', aquilo que chamaremos o caráter material do sentido das palavras e dos enunciados" (p. 146). Mais até do que uma maneira de interpretar a realidade, a formação ideológica é uma forma de se relacionar com ela, um modo de pensar e agir sobre a realidade, sob a ótica da luta de classes. Portanto, a formação ideológica tem um caráter social, pois representa o modo como um grupo pensa e age sobre o mundo. Ulteriormente, são as formações ideológicas que determinarão as formações discursivas que, por seu turno, constituirão o universo de sentidos dos sujeitos. Cada formação ideológica, pois, é representada por formações discursivas.

Pêcheux (2014) entende a formação discursiva como intrinsecamente associada à formação ideológica, tanto que desenvolve este conceito da seguinte maneira:

Chamaremos, então, formação discursiva aquilo que, numa formação ideológica dada, isto é, a partir de uma posição dada numa conjuntura dada, determinada pelo estado da luta de classes, determina o que pode e deve ser dito (articulado sob a forma de uma arenga, de um sermão, de um panfleto, de uma exposição de um programa etc.). (p. 147 - Grifos nossos)

Para o filósofo francês, a formação discursiva é tida como o lugar da constituição do sentido; a matriz mesma dos sentidos, já que o "recrutamento" ideológico ocorre pela via da FD:

(...) as palavras, expressões, proposições etc., recebem seu sentido da formação discursiva na qual são produzidas: (...) diremos que os indivíduos são 'interpelados' em sujeitos-falantes (em sujeitos de seu discurso) pelas formações discursivas que representam 'na linguagem' as formações ideológicas que lhes são correspondentes. (p. 147-Grifo nosso)

Pode-se concluir que as formações ideológicas são compostas por práticas, atitudes e ações que são coerentes com a posição política de determinados grupos na sociedade e, atrelados a estas FI, encontram-se frases, enunciados e textos que expressam e representam tais práticas sob forma linguística. A formação discursiva seria, então, o conjunto destes enunciados que representam as ideias, as práticas e as 
posições políticas de uma dada formação ideológica. Pode-se dizer, portanto, que a formação discursiva é a parte da formação ideológica feita de linguagem (feita de palavras, frases, textos etc.).

Uma vez de posse desses conceitos, investigar-se-ão, ao longo desta exposição, quais as formações ideológica e discursiva sustentam o discurso da "uberização" do trabalho. Antes, contudo, tratemos do corpus e do dispositivo de análise apresentado neste artigo, tendo a sequência discursiva de referência (SDr) - "menos direitos e emprego ou todos os direitos e desemprego" - como elemento organizador das demais formas de discursos trazidos à baila, imagéticos e textuais, em nosso gesto de descrição e interpretação. Entende-se SDr em conformidade com a teoria de Courtine (2016):

Precisamos primeiro conceber as determinações específicas ao nível da formulação [o intradiscurso]: escolher uma sequência discursiva - enquanto manifestação da realização de um intradiscurso - como ponto de referência a partir do qual o conjunto de elementos do corpus receberá a sua organização; relacionar essa sequência discursiva a um sujeito e a uma situação de enunciação determinada; mostrar como o sujeito da enunciação e as circunstâncias enunciativas são atribuíveis (referenciáveis) aos lugares dentro dos aparelhos ideológicos de uma determinada conjuntura histórica. Nós chamamos o conjunto de elementos que foram mencionados como as condições de produção da sequência discursiva da referência. (p. 25 - Grifos nossos)..

Seguindo essa exposição, esta pesquisa constitui como corpus, além da SDr (a sequência que organiza outros dizeres pré-existentes ou acessórios sobre o discurso analisado e que, por sintetizá-los, é tomada como referencial), sequências discursivas que a orbitam e com ela dialogam, extraídas do site da empresa Uber e da rede social Twitter do general Hamilton Mourão, vice-presidente da República. Além das sequências discursivas textuais, também é trazido à análise o componente imagético que as acompanham, por entender que este é elemento essencial da composição discursiva em exame, constituindo, assim, o nosso próprio objeto de estudo: o discurso políticoeconômico sobre a "uberização" do trabalho e os efeitos de sentido recuperados/deslizados na fala do presidente e do vice-presidente acerca de (neo)liberalismo e empreendedorismo.

O corpus, como acima delimitado, representa a superfície linguística e discursiva, "o material de linguagem bruto coletado, tal como existe" (ORLANDI, 2005, p. 63). Dessa maneira, o percurso que nos faz ir da superfície textual-imagética (a materialidade) ao discurso, através do objeto definido pelo corpus, faz-se por etapas: 1) passa-se da superfície linguística (sequências discursivas, textos, imagens) para 2) o objeto discursivo (a formação discursiva) e, finalmente, em direção ao 3) processo discursivo (momento em que se verifica a formação ideológica dos sujeitos).

Na primeira etapa, o/a analista incide seu primeiro gesto de análise sobre o texto, buscando o dito, isto é, a materialidade discursiva; esta "funciona como a porta de entrada para a elucidação de sentidos do discurso" (FLORÊNCIO et al, 2016, p. 87). Nessa fase, dá-se o processo descritivo, quando o/a analista busca nomear os recursos linguísticos empregados e as materialidades discursivas não-verbais, mas que compõem a significação, como as imagens. Uma vez concluída a descrição dos ditos, passa-se ao 
objeto discursivo, momento em que o/a analista passará a observar as formações discursivas distintas. É nessa ocasião em que se observam o não-ditos, apenas apreensíveis a partir dos ditos; nessa fase, as metáforas, as metonímias, os lapsos, as falhas importarão ao/à analista, constituindo as chaves das explicações oferecidas. Finalmente, a partir das FD, chega-se à etapa em que se analisam as formações ideológicas que regem as relações de sentido estabelecidas. Neste estágio, a partir do não-dito, pode-se proceder à análise do que foi silenciado. $\mathrm{O}$ interdiscurso, atravessando a materialidade linguístico-discursiva trazida na descrição, precisa ser aqui explicitado, mostrando como ele promove deslizamento de sentidos, deslocamentos e condensações dos sujeitos enunciatários.

\section{PROCESSO LINGUÍSTICO-DISCURSIVO DE “UBERIZAÇÃO” CONDIÇÕES DE PRODUÇÃO DO DISCURSO}

Como o próprio nome sugere, a empresa Uber remete a status. Em seus sentidos etimológicos oriundos do alemão, o radical "über" significa "acima", "sobre", "super". Incorporado ao inglês americano, no centro do capitalismo global, "uber" adquire outros sentidos, denotando algo que se intensifica, tanto como advérbio (como em This book is uber interesting", em que "uber" opera do mesmo modo que "very", "muito", como um advérbio de intensidade), ou como adjetivo, significando "superior", "o melhor" (como em The uber model Gisele Bündchen ${ }^{7}$ ). Uma vez que a Uber se origina da cultura de empresas de tecnologia do Vale do Silício californiano, tomaremos o sentido da palavra como o comumente utilizado e aceito nos Estados Unidos, em detrimento do sentido mais restrito originário do tronco linguístico germânico.

No português brasileiro, ocorre, contudo, uma transformação tanto linguística quanto semântico-discursiva da palavra "uber". Passemos à análise do mecanismo morfossintático que nos leva à "uberização". A partir do radical aqui considerado, há o acréscimo do sufixo -izar, ocorrendo a transformação de um substantivo (a empresa Uber) em verbo (uber > uberizar). Este processo de formação de palavras chama-se, na gramática normativa do português, de derivação sufixal ou sufixação (ainda que saibamos que "uberização" é um neologismo). Através do mesmo processo de derivação, mas desta vez com o acréscimo do sufixo -ção, ocorre novo rearranjo linguístico, desta vez transformando o novo verbo em substantivo (uberizar > uberização), substantivo este que indica um fenômeno em processo, em desenvolvimento.

A partir desta entrada linguística, pois, pode-se fazer uma equivalência com o pensamento de Pêcheux (2015), que enxerga a estrutura (linguística) encontrando o acontecimento (no caso em tela, o processo de precarização do trabalho); neste ponto nodal de encontro entre estrutura e acontecimento, verifica-se o discurso.

Já expusemos que o discurso político-econômico da "uberização" é aventado por sujeitos alinhados à formação ideológica do capital. Este discurso produz efeitos de sentidos nos/as trabalhadores/as de que 1) é necessário trabalhar através do empreendimento de si mesmo, sem vinculação a leis trabalhistas que assegurem contratos de trabalhos com direitos e deveres; e 2) que, através do empreendedorismo,

\footnotetext{
6 "Este livro é superinteressante!"

7 “A grande modelo Gisele Bündchen".
} 
o/a trabalhador/a conseguirá ter várias benesses, como mais flexibilidade para trabalhar, menos burocracia, ganhos materiais vultosos. Assim, este discurso, ao interpelar os sujeitos, gera efeitos de sentido que ressoam o dizer presidencial: com "menos direitos", aqui entendido como a burocracia necessária para se firmar um contrato de trabalho entre empregador-empregado, tem-se o emprego; ao revés, dispondo de "todos os direitos", perdem-se as benesses anunciadas, logo, tem-se desemprego.

É preciso que se volte às condições de produção desse discurso para entender por que ele vem sendo engendrado tão eficazmente. Segundo Jean-Jacques Courtine (2016), a análise de um processo discursivo se ancora na abordagem de zonas de trabalho, a saber: as condições de produção do discurso e a constituição de um corpus discursivo (como acima já delimitado); a seleção de palavras-chave na definição de entradas de um tratamento; e a conceituação da relação enunciação/enunciado. Afirma Courtine:

A noção de condições de produção do discurso regula, em $\mathrm{AD}$, a relação entre a materialidade linguística de uma sequência discursiva e as condições históricas que determinam sua produção; ela funda, assim, os procedimentos de constituição de corpus discursivos (conjunto de sequências discursivas dominadas por um determinado estado, suficientemente homogêneo e estável, das condições de produção do discurso). (COURTINE, 2016, p. 20)

Quando se discute a "uberização" no Brasil, pensa-se em um fenômeno recente, intimamente relacionado ao surgimento das tecnologias de aparelhos celulares do tipo smartphone - e sua disseminação entre a população - no início da década de 2010. No entanto, as bases históricas que permitiram o surgimento dessa nova forma de exploração da força de trabalho remontam mesmo ao passado do Brasil Colônia enquanto satélite do modo de produção pré-capitalista do império português. Aqui, país do capitalismo periférico, fundado como colônia de exploração (SCHWARCZ; STARLING, 2015) e regido sob a mais sádica lógica de mercado - que aprofunda ainda mais a exploração do homem sobre o homem, nem que, para isso, seja necessário recorrer a violentas formas estatais de submissão de outrem, como o foi a escravidão; neste país, como anunciamos, a lógica do capital precisa de formas autoritárias para se realizar. A herança aqui deixada foi a do patrimonialismo e a da bruta exploração da mão de obra: a economia colonial sempre recorreu à força para subjugar os povos nativos e escravizar a população negra e parda. Assim, geravam-se lucros para os senhores de engenho e para os burocratas da Corte portuguesa, enquanto a massa de trabalhadores, que ia constituindo a nação que se transformaria em Brasil, realizava o trabalho sem receber nenhum tipo de qualificação educacional, inserção digna na sociedade ou, sequer, contrapartida pecuniária por seus esforços.

Ainda que o país tenha atravessado mudanças ao longo de cinco séculos, sua estrutura social permanece basicamente a mesma: empresas estrangeiras se instalam em território brasileiro e utilizam mão de obra nacional, enquanto grandes latifundiários e/ou empresários, detentores do capital financeiro e das propriedades, comandam a economia, o Direito e a política do país - e, quando há ameaças ao seu protagonismo, esta burguesia não se escusa de manobrar as regras jurídicas que ela mesma colocou para configurar o Estado, chegando mesmo a entregar o poder a aparatos políticomilitares, golpeando governos que permitiam, ainda que minimamente, certa 
mobilidade na rígida hierarquia social brasileira. Assim aconteceu com Getúlio Vargas em 1954, com João Goulart dez anos depois e com Dilma Rousseff em 2016.

No Brasil, a chaga da escravidão e do latifúndio ainda lança sua sombra sobre o mundo do trabalho. Com a abolição, em 1888, enorme contingente populacional foi entregue à própria fortuna. Sem emprego e sem qualificação profissional que os habilitasse a trabalhar, os novos homens e mulheres livres continuaram a ocupar subempregos, sem projeto que os integrasse à sociedade e sem garantias de direitos por parte do Estado brasileiro. Somente a partir do governo de Getúlio Vargas houve avanços na seara trabalhista, com a criação da Justiça do Trabalho e, em 1943, com o decreto da Lei 5.452, a qual estabelecia a Consolidação das Leis do Trabalho (CLT). Este dispositivo jurídico representou um avanço histórico quanto às relações laborais, uma vez que passou a regulamentar tanto o trabalho urbano como o rural num país em que, embora essencialmente agrícola, observava-se uma incipiente massa urbana. Criada no Estado Novo varguista, a supracitada lei tinha como objetivo coibir as relações abusivas no trabalho: determinou direitos e deveres dos empregadores e dos empregados, igualdade salarial para os que prestavam o mesmo tipo de serviço, vinculação empregatícia a quem trabalhava regularmente em uma empresa, duração de jornada de trabalho, normas para fixação de horas extras, dentre outras proteções que visavam assegurar direitos mínimos aos trabalhadores.

No entanto, o mundo do trabalho no Brasil atual vem se transformando; poderse-ia dizer mesmo que regredindo no tocante aos direitos do trabalhador, devido a um amálgama de fatores especialmente perversos: só para restarmos na atualidade, o Brasil passou de uma situação de quase pleno emprego em 2014 (curiosamente, o ano da chegada da Uber ao Brasil, durante a Copa do Mundo), quando se registrou 4,8\% de desempregados em agosto do referido ano de acordo com o Instituto Brasileiro de Geografia e Estatística (IBGE) - para um cenário de desemprego estrutural e crônico em 2020 (atingindo, no corrente mês de novembro, um recorde de 14,4\% segundo o mesmo $\mathrm{IBGE}^{8}$, índice este mantido estável acima dos dois dígitos desde 2016, quando do golpe parlamentar que retirou o comando governamental do Partido dos Trabalhadores); vivencia-se um período de crescimento inexpressivo da renda, após anos sucessivos de políticas de valorização do salário mínimo; ocorre a diminuição, a erosão ou mesmo a eliminação de direitos a partir da "reforma trabalhista" de Michel Temer, realizada em 2017 como um necessário "modernizador" do mercado de trabalho, tendo como mote a "flexibilização" e a adequação da "obsoleta" CLT, com uma falsa promessa de que, com esse amargo remédio, gerar-se-iam milhões de empregos - a realidade, no entanto, mostra que mais de 6 milhões de desempregados ou subempregados foram acrescidos à equação do desalento ocupacional, além de ter

\footnotetext{
${ }^{8}$ Resultado da PNAD Contínua (Pesquisa Nacional por Amostra de Domicílios - IBGE) realizada em agosto de 2020 e publicada em novembro do mesmo ano. "PNAD Contínua: taxa de desocupação é de $14,4 \%$ e taxa de subutilização é de 30,6\% no trimestre encerrado em agosto de 2020". Disponível em: https://agenciadenoticias.ibge.gov.br/agencia-sala-de-imprensa/2013-agencia-de-noticias/releases/29322pnad-continua-taxa-de-desocupacao-e-de-14-4-e-taxa-de-subutilizacao-e-de-30-6-no-trimestre-encerradoem-agosto-de-2020.
}

9 “Aprovada em 2017, a reforma trabalhista alterou regras para flexibilizar o mercado de trabalho". Disponível em: https://www12.senado.leg.br/noticias/materias/2019/05/02/aprovada-em-2017-reformatrabalhista-alterou-regras-para-flexibilizar-o-mercado-de-trabalho. 
jogado o país à marca de $41,4 \%$ de sua população empregada na informalidade - uma contradição em si mesma.

Em outros termos: houve aumento de trabalhadores que, para exercer suas atividades, submetem-se a trabalhos precários, prestando serviços à margem das garantias básicas preconizadas pela CLT, de maneira informal. Demais efeitos da "reforma" de 2017 levaram ao enfraquecimento dos sindicatos de representação dos/as trabalhadores/as e à piora na qualidade de vida dos/as mesmos/as, que encontraram maiores obstáculos até mesmo para ajuizar processos trabalhistas na Justiça ${ }^{10}$, já que, em muitos casos, a "reforma" retirou a segurança do/a trabalhador/a e o/a levou a pagar as custas processuais em caso de perda da ação movida. O contraditório discurso do governo Temer, sustentado na promessa da geração massiva de empregos a partir da "flexibilização" e da modernização do trabalho, trouxe, em sua verdade material e inescapável, apenas a precarização.

À medida que estas nefastas transformações sociais aconteciam, empresas da chamada gig economy, ou "economia dos bicos", encontraram ambiente favorável para expandir sua atuação no Brasil. Enquanto a desindustrialização ${ }^{11}$, tendência da política econômica brasileira observada desde a década de 1990 (quando da implantação da agenda neoliberal no país), era acelerada, concorria para o enfraquecimento da cadeia produtiva nacional a paralisação das obras de infraestrutura ${ }^{12}$ do ciclo dos governos petistas, ocasionando o aumento do desemprego. Assim, grande parte da massa de trabalhadores/as precisou se voltar para atividades informais como meio de sobrevivência, engajando-se em atividades como a proposta pela Uber.

Como modo de produção dominante, o capitalismo centra suas atividades na produção e na constante inovação para torná-la célere. Enquanto as sociedades baseadas em outros modos de produção se caracterizavam pela relativa estabilidade das relações econômicas e sociais, o capitalismo é marcado pela revolução permanente. Essa instabilidade permitiu diversas transformações tecnológicas em curto espaço de tempo. A gig economy representa mais uma dessas inovações inerentes ao redesenho do capitalismo. Sem inovações, os capitalistas, submetidos à lei

\footnotetext{
${ }^{10}$ Sobre tais efeitos, recomenda-se a leitura do artigo intitulado "Em um ano, reforma trabalhista aumenta informalidade e enfraquece sindicatos". Disponível em: https://reporterbrasil.org.br/2018/11/em-um-anoreforma-trabalhista-aumenta-informalidade-enfraquece-sindicatos/.

${ }^{11}$ Sobre o tema, recomenda-se a leitura do artigo do Portal da Indústria da CNI (Confederação Nacional da Indústria): "Indústria brasileira é a $16^{\mathrm{a}}$ em participação na produção mundial do setor, aponta CNI". O artigo afirma: "Em trajetória de queda desde 2009, a participação do Brasil na produção industrial mundial caiu de 1,24\%, em 2018, para 1,19\%, em 2019. É o piso da série histórica iniciada em 1990. Até 2014, o Brasil figurava entre os 10 maiores produtores no ranking mundial". Disponível em: https://noticias.portaldaindustria.com.br/noticias/economia/industria-brasileira-e-a-16a-em-participacaona-producao-mundial-do-setor-aponta-cni/.

12 "Pesquisa identifica quase 5 mil obras do PAC paralisadas no país". O PAC (Programa de Aceleração do Crescimento) foi iniciativa do governo Lula, continuada no governo Dilma, responsável por grandes obras de infraestrutura, como a transposição do Rio São Francisco, pavimentação de estradas, construção de moradias e de unidades de saúde, além dos estádios da Copa do Mundo de 2014 e parte da estrutura das Olímpiadas do Rio de 2016. Na matéria, lê-se: "A iniciativa do governo petista teve prosseguimento na gestão da presidente Dilma Rousseff, mas foi praticamente paralisada quando Michel Temer assumiu o comando do Palácio do Planalto". Disponível em: https://g1.globo.com/politica/noticia/2019/04/10/pesquisa-identificaquase-5-mil-obras-do-pac-paralisadas-no-pais.ghtml.
} 
da competição inter e intragrupos, com industriais competindo com industriais, mas também com banqueiros e comerciantes (NETTO; BRAZ, 2012), sucumbem e não sobrevivem no mercado.

Inovar, logo, é uma necessidade de sobrevivência material - mormente na hodierna configuração do sistema, que faz aumentar o capital através de movimentações financeiras, sem a participação direta na produção de bens. Ao analisar o fenômeno da inovação já no Manifesto Comunista, diz Marx e Engels (2012, p. 32), em uma das passagens famosas do texto: "A burguesia não pode existir sem revolucionar continuamente - ou seja, as relações de produção -, isto é, o conjunto das relações sociais". No modelo de Marx, o capitalista busca aumentar a massa de mais-valor que extrai de seus trabalhadores. Com o cenário de falta de ocupação na indústria e na construção civil, o capital brasileiro volta-se às atividades de serviços e precisa, portanto, flexibilizar as regras trabalhistas no setor para que continue a obter lucros. A isto viemos chamando de processo de "uberização" do trabalho. E, se a "uberização" não centra seu lucro na produção de mercadorias (mais-valor relativo), o capitalista necessariamente terá de aumentar seus lucros fazendo seus empregados trabalharem por mais horas que a concorrência (mais-valor absoluto).

\section{A UBER E O ENGENDRAMENTO DE SENTIDOS DE “LIBERDADE" E "PARCERIA"}

Um dos ícones dessa nova dinâmica de (re)produção do capital pela exploração do trabalho é a Uber $^{13}$, empresa norte-americana que assevera em seu discurso oficial ser mera empresa de tecnologia que oferece serviços de transporte, sem se identificar como uma empresa de transporte de fato. Identifica-se, portanto, como um "aplicativo", um "facilitador" entre um prestador de serviço e um usuário deste serviço, sem querer vincular-se ao trabalhador que executa a tarefa de transportar pessoas e encomendas pelas cidades. A esse respeito, diz Ricardo Antunes (2018):

A Uber é [...] exemplo mais do que emblemático: trabalhadores e trabalhadoras com seus automóveis, isto é, com seus instrumentos de trabalho, arcam com suas despesas de seguridade, com os gastos de manutenção dos veículos, de alimentação, limpeza etc., enquanto o "aplicativo" - na verdade, uma empresa privada global de assalariamento disfarçado sob a forma de trabalho desregulamentado - apropria-se do mais-valor gerado pelo serviço dos motoristas, sem preocupações com direitos trabalhistas historicamente conquistados. Em pouco tempo, essa empresa se tornou global, com um número espetacularmente grande de motoristas que vivenciam as vicissitudes dessa modalidade de trabalho instável. (p. 35 - Grifo nosso)

\footnotetext{
${ }^{13}$ Em meio às polêmicas em torno da questão trabalhista, a investida da empresa no mundo do trabalho começa a se ampliar com a versão teste da Uber Works, que pretende conectar empresas que precisam de funcionários temporários a quem busca esse tipo de trabalho. Este fato parece reforçar a tese que aqui defendemos, a da expansão da "economia dos bicos" e da "uberização" do trabalho.
} 
Estruturadas primordialmente pelo uso das novas tecnologias digitais e pela falta de vínculos estreitos entre quem presta o serviço e quem o contrata, empresas de tecnologia que operam através de aplicativos de celulares, como a Uber, asseveram ser apenas mediadoras de serviços, não podendo ser responsabilizadas diretamente pelos que se "voluntariam" a trabalhar com elas, conforme se lê no sítio digital da empresa: "A Uber oferece uma plataforma tecnológica para que motoristas parceiros se conectem de forma fácil e descomplicada a usuários que buscam viagens acessíveis e confiáveis" (grifo nosso). Assim, livram-se de obrigações básicas que competem a quaisquer empregadores no Brasil, como o pagamento de contraprestação pecuniária pelo tempo de serviço (salário fixo), horas extras, adicionais noturnos, folga semanal, férias remuneradas, décimo terceiro salário, recolhimento de impostos à seguridade social etc. Mas estes aspectos negativos são silenciados no discurso oficial da empresa, que prioriza traços positivos em seu dizer: "Possibilitamos que motoristas profissionais possam ter ainda mais oportunidades de ganhar dinheiro ao conectá-los com usuários que desejam se deslocar pela cidade" (UBER, 2020).

Não se informa, entretanto, como os motoristas ganham dinheiro a não ser por sua própria força de trabalho, com seus próprios veículos. A empresa se apresenta como uma facilitadora, um meio que possibilita o serviço - não como a empregadora, como a que realmente lucra com a exploração da força de trabalho vendida. Vejam-se as figuras a seguir, extraída do site oficial da Uber com dizeres que reforçam o que acaba de ser exposto.

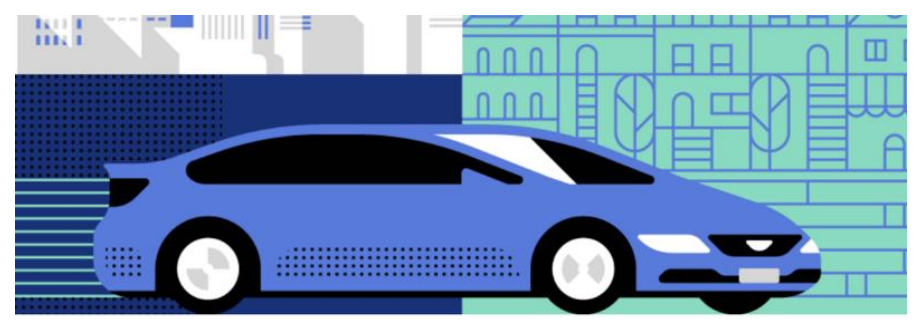

$$
\begin{aligned}
& \text { A Uber é uma empresa de tecnologia que está transformando a } \\
& \text { maneira como pessoas se movimentam. Ela conecta usuários e } \\
& \text { motoristas parceiros por meio de seu app. }
\end{aligned}
$$

Figura 1. Propaganda-comunicação no website da Uber.

Faça seu próprio horário
Você decide quando quer ganhar dinheiro dirigindo.

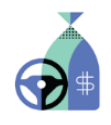

Faça um bom dinheiro

Você decide quando quer ganhar dinheiro dirigindo. Quanto mais vocé dirigir, mais poder ganhar. Além disso, os valores sảo depositados automaticamente toda seman

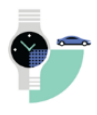

Defina seu próprio horário

Dirija somente quando for melhor para você. Sen escritório nem chefe. Isso significa que vocé pode começar e parar quando quiser. Na uber, $\theta$ você quem manda

Figura 2. Página da Uberna internet dirigida a novos motoristas "parceiros".

Primeiramente, faz-se mister apontar a peça publicitária/de comunicação no sítio online da empresa, dirigida aos "motoristas parceiros". Note-se que, na figura 1 , ante 
um carro que aparenta ser espaçoso, confortável, moderno e veloz, há uma sequência discursiva em que a Uber reafirma ser "uma empresa de tecnologia", sendo um meio (um app) de conexão entre "usuários e motoristas parceiros". Já na figura 2, há uma lista de benesses oferecidas estes "parceiros", acrescidas de imagens que remetem a tempo e a dinheiro.

O empreendedorismo, um termo do universo da administração que significa "a iniciativa de implementar novos negócios ou mudanças geralmente com alterações que envolvem inovação e riscos" (OXFORD, 2020), é um dos motes do discurso da Uber. Percebe-se o valor neoliberal do empreendedorismo a partir de materialidades da figura 2: "faça um bom dinheiro"; "você decide quando quer ganhar dinheiro dirigindo", "Defina seu próprio horário. Dirija quando for melhor para você. Sem escritório nem chefe. [...] Na Uber, é você quem manda" (grifo nosso). Nota-se, assim, que os efeitos de sentido pretendidos tendem a ressaltar os supostos benefícios ao/à trabalhador/a que presta serviços à empresa; concomitantemente, a empresa, dissimulando na linguagem a exploração do trabalho em sua maneira tradicional (em um escritório, com um chefe "que manda"), confere um efeito de liberdade ao/à motorista, que teria a seu dispor tanto a possibilidade de ter uma renda mais alta do que o usual ("faça um bom dinheiro") quanto a flexibilidade de decidir os horários em que trabalha ("defina seu próprio horário").

Este discurso, que procura dissimular o real propósito da Uber (o lucro através da exploração), também procura confundir os indivíduos a respeito da natureza empregatícia de uma empresa que conta com vasta rede de trabalhadores/as à sua disposição para lhe gerar lucro com a mais-valia: a empresa se apresenta como sendo de tecnologia, não como de serviços. Perceba-se o dizer da figura 1. A Uber procura se apresentar como uma "empresa de tecnologia", algo muito apreciado e necessário no mundo globalizado. Isso produz efeitos discursivos que fazem com que a empresa encontre pouca resistência e gere consenso sobre sua natureza. "Quem, afinal de contas, pode lutar contra o futuro?" (SLEE, 2017, p. 142). Quem, afinal, seria contra um app que facilita a vida das pessoas nas cidades, "conectando usuários" a "motoristas parceiros" da empresa, pessoas que precisam de serviços de transporte no caótico cenário urbano brasileiro, com mais conforto e a preços mais baratos que transportes regulamentados, como táxis? Quem seria, enfim, contra a ideia de solucionar o problema da mobilidade urbana ao mesmo tempo em que se gera renda a trabalhadores/as?

Este é um efeito de sentido produzido pelo discurso da Uber, que, através do consenso, silencia a exploração de sua força de trabalho e os meios pelos quais os/as motoristas são habilitados/as para trabalhar para a empresa. São várias as demandas pedidas - dispor de sua força de trabalho a ser vendida, dispor de seu veículo, atingir metas -, mas não há nenhuma contrapartida que usualmente se verifica no mundo do trabalho formal. Todas essas características levam à conclusão que trabalhar para esta empresa refazem o percurso do enunciado do Presidente da República: sem os direitos formalizados, previstos pela legislação trabalhista, tem-se a garantia do emprego. Silencia-se, contudo, o fato de que este é um emprego precarizado, sem previsões legais a acobertar o/a trabalhador/a em momentos de necessidade, como com despesas médicas pagas pelo governo em caso de acidente de trabalho, ou o direito a recolhimento à seguridade social para aposentadoria, ou, ainda, sem o pagamento integral da corrida ao/à motorista, já que a empresa pode receber uma taxa que varia em 
até $40 \%$ de retorno, ficando em torno de $20 \%$ na maioria dos casos, num intricado cálculo que envolve o preço-base de viagem calculado pelo aplicativo, o preço por quilômetro percorrido e o preço por tempo de viagem ${ }^{14}$. Esta taxa variável de retorno à empresa é uma maneira de mostrar que há mais-valia na prestação do serviço, já que o/a empregado/a precarizado/a não recebe o retorno integral do serviço que prestou com seu próprio veículo.

Ao veicular a "parceria", engendra-se um efeito de sentido de que há uma relação de confiança entre o/a motorista que escolheu trabalhar para a Uber e a empresa; essa relação "parceira", que simula efeitos de amizade, e não de um contrato formal de trabalho, auxilia no projeto de desvinculação da Uber como uma empresa com direitos e deveres perante seus empregados. Afinal, como ela mesmo diz, é apenas um meio, uma facilitadora. Tal efeito de sentido deste discurso vem encontrando ressonância nas cortes superiores do país, como no Superior Tribunal de Justiça (STJ), o qual entendeu, em agosto de 2019, que os/as motoristas que prestam serviço à Uber Technologies Inc. não têm vínculo trabalhista com a empresa. Na decisão da corte, lê-se:

Os motoristas de aplicativo não mantêm relação hierárquica com a empresa Uber porque seus serviços são prestados de forma eventual, sem horários pré-estabelecidos e não recebem salário fixo, o que descaracteriza o vínculo empregatício entre as partes. (STJ, 2019).

É fundamental, contudo, observar que a Uber determina uma série de prérequisitos a seus "motoristas parceiros", os quais claramente configuram vínculos de trabalho. Como afirma Tom Slee (2017), a empresa, além de exigir que o "microempreendedor" entre com o aporte de bens - os veículos, o seguro, o combustível, as taxas e os impostos veiculares -, "tira vantagem da vulnerabilidade dos motoristas para impor regras mais e mais rigorosas. Os motoristas devem aceitar $90 \%$ dos pedidos ou recebem uma notificação: 'Por favor, melhore sua taxa de aceitação se quiser continuar a usar a plataforma da Uber"” (p. 143). Também sobre esta temática, Antunes (2018) diz que "[n]o sistema Uber [...] os/as motoristas não podem recusar as solicitações. Quando o fazem, sofrem represálias por parte da empresa, que podem resultar no seu 'desligamento"” (p. 35). Tal solicitação parece atender a exigência de "regularidade e frequência" na prestação de serviços, configurando, assim, o vínculo empregatício, conforme preconiza(va) a CLT em seu artigo terceiro:

Art. $3^{\circ}$ : Considera-se empregado toda pessoa física que prestar serviços de natureza não eventual a empregador, sob a dependência deste e mediante salário. (CLT, 1943). Grifo nosso.

Vê-se que, hodiernamente, a hermenêutica jurídica brasileira, como a estabelecida pelo entendimento do STJ trazido acima, afasta-se dos interesses do/a trabalhador/a, ao interpretar que o/a motorista ou entregador/a de aplicativo não pode ser considerado um/a empregado/a; e em não havendo, logo, um contrato de trabalho, tampouco há a possibilidade da parte hipossuficiente da relação trabalhista (ou seja, da

\footnotetext{
${ }^{14}$ Sobre este cálculo, a empresa preparou um vídeo voltado a seus "motoristas parceiros" explicando os ganhos do cálculo e por que a taxa de serviço que lhes é cobrada é importante para o funcionamento do serviço. Não se menciona por que o/a "motorista parceiro/a" não é tratado como empregado formalizado, já que está em funcionamento o sentido de "parceria". Disponível em: https://www.uber.com/pt$\mathrm{BR} / \mathrm{blog} /$ entenda-taxa-servico/.
} 
parte do trabalhador/a, de quem vende sua força de trabalho) de apelar contra decisões arbitrárias, como as queixas de usuários exigentes que por ventura reclamem do serviço prestado. Na falta de um gerente físico a controlar a jornada de trabalho e a produção, um dos pressupostos das cadeias produtivas tradicionais, a plataforma delega a função de gerenciamento do serviço a um sistema de pontuação altamente subjetivo que ocorre entre cliente transportado/a e motorista. Isto deixa os/as condutores/as ainda mais vulneráveis e pressionados/as, sem qualidade na atividade laboral, pois ficam constantemente ameaçados de serem "desligados" da empresa para a qual trabalham (e com a qual, saliente-se, não guardam vínculo jurídico), devido à vigilância e à pressão de se manterem com notas máximas perante os/as clientes.

Ademais, como a Uber ocupa a posição jurídica sui generis de não ser a empregadora ante os/as motoristas e entregadores/as que a ela se aliam, se algo der errado na prestação do serviço a empresa se ab-roga da obrigatoriedade de assumir quaisquer responsabilidades - em outras palavras, a empresa não precisa oferecer condições mínimas para o/a trabalhador/a oferecer seu serviço, apenas dele/dela se servindo na obtenção de lucro. Todos os riscos da atividade laboral - acidentes, erros de transporte/logística, auxílio-doença etc. - devem ser assumidos pelos/as subcontratados/as, por esse neoproletariado (ou seja, uma classe proletária inserida em novas ocupações, permitidas pela tecnologia, diferentemente do clássico estereótipo do operário do chão da fábrica). Hoje, mais de 600 mil destes "parceiros" trabalham para a Uber no Brasil, conforme a própria empresa informa. Tal realidade representa uma melancólica tendência de tipo de ocupação laboral, já que 24,3 milhões de pessoas estão atualmente trabalhando nestes moldes, isto é, por conta própria, conforme novo recorde registrado pelo IBGE. Pessoas que já vivem com menos direitos e que sequer contam com um "emprego", no sentido usual, qual seja, uma ocupação que conferia, ao menos, certa estabilidade e remuneração fixa.

É nesse contexto de profunda desregulação e seguridade laboral que a "uberização" surge como uma das formas cada vez mais comuns de ocupação econômica e organização do trabalho no Brasil. Tal acontecimento não é algo recente, surgido somente com o advento da tecnologia: é, na verdade, o resultado de décadas, mesmo séculos, de conformação do mundo do trabalho no Brasil, que deixa grande parte de sua população à margem do sistema educacional e, logo, de ocupações de maior remuneração. Como aponta a pesquisadora Ludmila Chostek (2014) ao tratar das revendedoras de cosméticos, o efeito de sentido assentado no "empreendedorismo" é um processo que data já algum tempo no país. Tal como a Uber, revendedoras de cosméticos de empresas como Avon, Natura e Jequiti também "trabalham quando querem", com seus próprios instrumentos, sem vínculos empregatícios. A diferença residia no fato de que, antes dos eventos do golpe de 2016, considerava-se tal atividade como um complemento de renda, representando uma expressão marginal do mundo do trabalho no Brasil; hoje, com o advento das "reformas" de cunho neoliberal, este tipo de ocupação vem se cristalizando como uma tendência que transforma profundamente as relações trabalhistas no país, sustentada pelo discurso que promove o empreendedorismo.

\section{O DISCURSO PALACIANO E SUA RELAÇÃO COM A "UBERIZAÇÃO" DO TRABALHO}


Uma vez tratado do discurso promovido pela Uber, que procura simular liberdade e parceira, silenciando o conflito de classes e a exploração dos/as trabalhadores/as nesta configuração, vejamos como este fenômeno se apresenta como uma tendência pertencente a um processo discursivo acerca do mundo do trabalho que antagoniza trabalhadores/as, de um lado, e grandes empresários/as do setor do capital financeiro e seus representantes políticos, de outro, processo este que atinge várias ocupações e as precariza, lançando-as à informalidade e à insegurança jurídica. Conforme a lição de Pêcheux (2014, p. 82), "todo processo discursivo se inscreve numa relação ideológica de classes", não devendo ser confundido com a fala (a parole), com uma utilização individual da língua, mas, antes, remete a práticas de classe. Avançará o autor no desenvolvimento deste conceito: “[...] a expressão processo discursivo passará a designar o sistema de relações de substituição, paráfrases, sinonímias etc., que funcionam entre os elementos linguísticos - 'significantes' - em uma formação discursiva dada" (PÊCHEUX, 2014, p. 148). Uma vez feita a relação entre o discurso do presidente Jair Bolsonaro, que naturaliza a exploração da força de trabalho a partir da retirada de direitos para que se tenha emprego, com o discurso da Uber, que simula a liberdade e a parceira enquanto se explora o/a trabalhador/a, analisemos sequências discursivas, textuais e imagéticas, de outro representante do Palácio do Planalto, o vicepresidente do governo que ora ocupa Brasília.

A "flexibilização", ou melhor, a desvinculação de garantias trabalhistas que se implementa no Brasil hodierno é sustentada, como visto, pela ideologia neoliberal, a qual privilegia o individualismo, o empreendedorismo, a competição, a pulverização das relações sociais no labor e, consequentemente, a falta de solidariedade entre os/as trabalhadores/as, já que se encontram dispersos/as uns/umas dos/as outros/as em seus serviços e são encorajados/as a competir com seus pares. De acordo com este ideário, ao Estado cabe um papel menor, de mero gerenciamento da burocracia administrativa, delegando ao mercado e ao livre capital as funções que lhe competiria, reforçando o patrimonialismo e privatizando setores-chave de desenvolvimento estatal, como a educação, a saúde, a segurança pública, os investimentos em infraestrutura e as políticas de geração de empregos.

A ideologia neoliberal se tornou mais expressiva no cenário brasileiro a partir do golpe de 2016, aprofundando-se a partir deste período e sendo continuado com o governo de Jair Bolsonaro. O vice-presidente da República é um exemplo deste receituário ideológico. Tome-se como exemplo a série de tweets do general Mourão, explicitamente exaltando os valores do (neo)liberalismo pela via da memória discursiva:
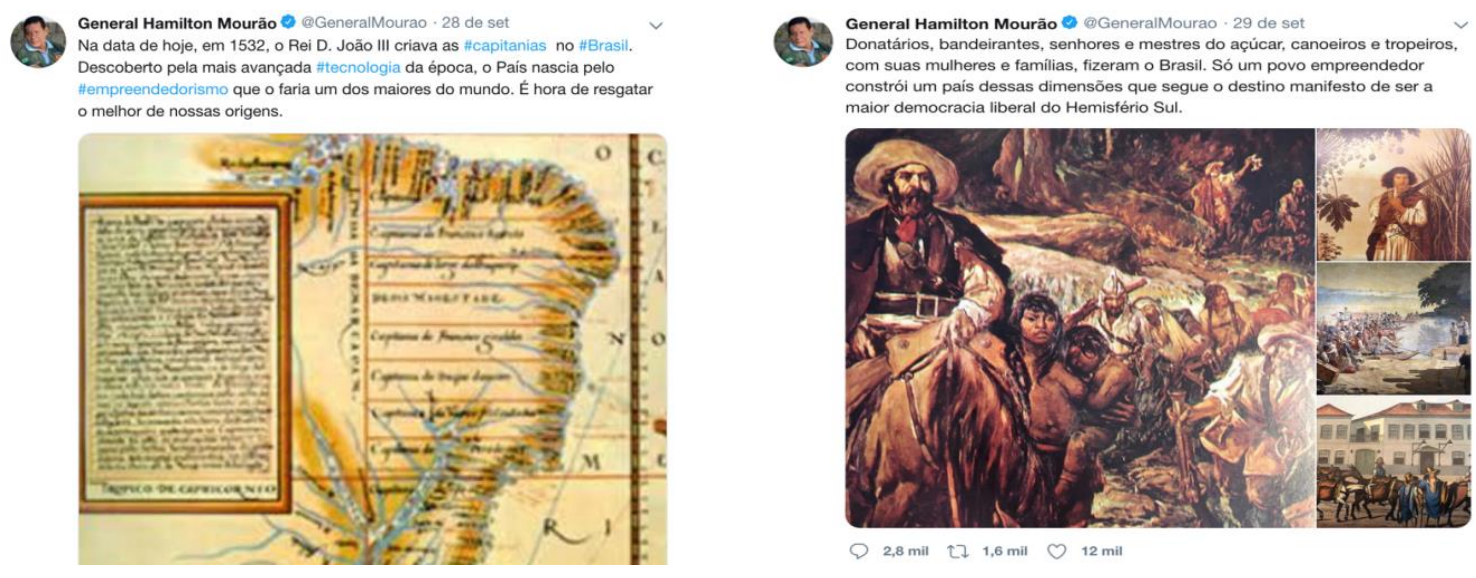


\section{Figuras 3a e 3b. Postagens de Hamilton Mourão, vice-presidente da República, na rede social Twitter.}

Os dizeres do vice-presidente apresentam-se bastante alinhados à ideologia neoliberal que sustenta seu governo. Notem-se as materialidades discursivas que ele procura dar destaque por meio de cerquilhas ("hashtags"): capitanias, Brasil, tecnologia, empreendedorismo. Assim, na textualidade que apresenta, percebe-se o funcionamento da formação ideológica do capital na formação discursiva na qual se inscreve, que lhe serve de matriz de sentidos e que rege o que pode e deve ser dito (PÊCHEUX, 2014).

Enquanto aclama abertamente a "democracia liberal" e o "empreendedorismo", esquece-se o general que seus (nossos) ancestrais foram submetidos a verdadeiro genocídio para a implementação das Capitanias Hereditárias, um empreendimento altamente patrimonialista e hierárquico fadado ao fracasso e suplantado por outro modelo, igualmente "empreendedor" e fracassado - o dos Governos-Gerais (SCHWARCZ; STARLING, 2015). Na figura 3a, percebe-se o mapa do Brasil recortado em Capitanias Hereditárias, as quais, no dizer do segundo postulante ao cargo máximo da República, foram um caso de sucesso do empreendedorismo e da tecnologia da época - e não um acordo entre a Coroa portuguesa e nobres para não deixar o território recém-empossado à mercê da exploração de estrangeiros. $\mathrm{O}$ vice-presidente procura acionar uma memória com o fito de exaltar o "empreendorismo" através do uso da "tecnologia", dentro da "democracia liberal" - note-se que tais materialidades discursivas são recorrentes quando tratamos de "uberização" na conjuntura atual. Também vale salientar que a fala do general recupera elementos de saber já anteriormente proferidos e por ele devidamente atualizados: a "tecnologia da época" permitiu que o Brasil se constituísse enquanto tal, fruto do "empreendedorismo". Podese fazer um paralelo entre a tecnologia sendo um pilar do empreendedorismo tanto em 1532, como afirma o general, quanto em 2020, num movimento do discurso do capital que procura fazer do empreendedorismo uma alternativa ao trabalho formal (a tecnologia da Uber, por exemplo, é o que propicia isso).

Ao afirmar que "é hora de resgatar essas origens", adequando fatos passados há quase cinco séculos para engendrar o sentido de que o empreendedorismo é o "destino manifesto" do Brasil para se tornar a "maior democracia liberal do Hemisfério Sul", percebe-se o funcionamento do interdiscurso, o "todo complexo de discursos" (PÊCHEUX, 2014), no intradiscurso (o dizer atual) de Mourão. Courtine (2016) entende que o interdiscurso está localizado num eixo vertical, no nível do enunciado, como "uma instância de formação/repetição/transformação dos elementos de saber de uma formação discursiva" (p. 23); quanto ao intradiscurso, diz o autor que

[é] o lugar onde se realiza a sequencialização dos elementos do saber, onde desnivelação interdiscursiva do [E] [o enunciado, o repetível, o formulado $e$ o reformulado] é linearizada, provocando um achatamento em uma superfície única de [e] [a própria formulação] articuladas. [É a] "horizontalização" da dimensão vertical de constituição do enunciado. (COURTINE, 2016, p. 24)

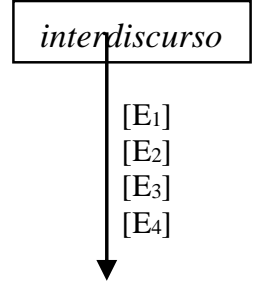


$\left[\mathrm{E}_{5}\right]$

intradiscurso $\left[e_{1}\right]\left[e_{2}\right]\left[e_{3}\right]\left[e_{4}\right]\left[e_{5}\right]\left[e_{6}\right] \ldots$

Figura 2. Esquema representativo do atravessamento do interdiscurso sobre o intradiscurso.

No esquema acima, [E] representa instâncias do interdiscurso que possibilitam a repetição/reformulação/paráfrase; [e] representa o sintagma posto no momento da formulação de um dizer, elementos do intradiscurso, o "fio do discurso". Percebe-se que o interdiscurso atravessa, pois, o intradiscurso, dessa forma também lhe constituindo, sustentando a possibilidade mesma do dizer.

Observe-se, ademais, que a produção de sentidos do discurso do general Mourão opera para que haja o silenciamento tanto do genocídio dos povos nativos, promovido em larga escala pelas entradas e bandeiras de exploração do território nacional, quanto da crueldade da escravidão, que sustentou o modo de produção dos engenhos de canade-açúcar. Traz-se, em primeiro plano, os bandeirantes representados na imagem da figura $3 b$; note-se que os índios estão numa posição inferior ao bandeirante, montado em seu cavalo, "senhor" desse lugar, "grande empreendedor" a guiar a população brasileira. Também se desvela, nesta postagem, o papel subalterno que a mulher ocupa nesta sociedade exaltada pelo vice-presidente. Há farta apologia ao trabalho de quem ocupava o topo da hierarquia da sociedade colonial brasileira: "donatários, bandeirantes, senhores e mestres do açúcar, canoeiros e tropeiros [pequeno-burgueses e artesãos livres], com suas mulheres e famílias, fizeram o Brasil". A formação discursiva na qual o general se inscreve, determinando-lhe o que pode e deve ser dito, não permite que apareça, na linguagem, o óbvio da violência e da desigualdade que seu projeto de "empreendedorismo" comporta - sendo necessário, portanto, apontarmos claramente essas contradições, realizando uma crítica à afirmação do óbvio (PÊCHEUX, 2014) que ele apresenta como evidente e opaco.

O que se dissimula na linguagem, querendo apresentar-se como transparente, termina por sustentar o discurso da "uberização": o empreendedorismo, ou seja, a "vontade" de trabalhar por conta própria, já que não há empregos disponíveis, visto que a cadeia produtiva nacional se encontra em processo de enfraquecimento (desindustrialização, paralisação da construção civil). A ocupação formal, tornando-se mais rara, abre espaço à informalidade e à precarização, fazendo com que o/a trabalhador/a que precisa de uma fonte de renda se submeta a trabalhos intermitentes, instáveis, de renda imediata, sem direitos e deveres chancelados por instâncias legais que empreenda, enfim. Assim, o discurso do empreendedorismo, aclamado pelo vicepresidente Mourão, também acena ao discurso da "uberização" e, uma vez mais, ao discurso do presidente Jair Bolsonaro, tomado como SDr.

Já se identificaram as condições de produção do discurso da "uberização" e alguns de seus sujeitos enunciativos (Mourão, a própria empresa Uber), que formulam em seu intradiscurso elementos de saber que recuperam, a nível interdiscursivo, valores ideológicos que se materializam linguisticamente em "empreender" (e seus derivados), "trabalho" (e seus derivados), "direitos" (e seus derivados). Nada parece mais cristalino (se é que é a linguagem pode, de fato, ser transparente) quanto a sequência discursiva que tomamos como de referência (SDr): "O trabalhador vai ter que decidir um dia: menos direito e emprego ou todos os direitos e desemprego" (grifo nosso). Essas 
orações foram proferidas em entrevista à jornalista Leda Nagle em abril de 2019, por meio das redes sociais, sendo Jair Bolsonaro seu sujeito enunciativo. Fica patente, assim, que o presidente brasileiro demarca sua posição de classe, qual seja, a da classe dominante, alinhado, portanto, à formação ideológica do capital. Para isto, dirige-se aos/às trabalhadores/as de forma direta ("o trabalhador vai ter que decidir um dia"), dando-lhes um ultimato: "menos direito e emprego ou todos os direitos e desemprego". Esta SDr, como visto ao longo de nossa exposição, carrega uma longa trajetória discursiva que tem como objetivo último a precarização do trabalho, ou, se preferirmos, a "uberização" do trabalho.

A partir desta entrada, expõe-se mais perceptivelmente o ideário neoliberal, que dissimulava, na fala do general Mourão, ou mesmo na "reforma" proposta por Temer, a ideia de que "flexibilizar" os direitos trabalhistas e "empreender" passaria a ser uma alternativa ante o desemprego crescente. A fala do mandatário do Brasil evidencia o caráter classista da sociedade brasileira, que escolheu como presidente alguém que não cuida do/a trabalhador/a, delegando-lhe a responsabilidade de ser seu/sua próprio/a provedor/a, ainda que as condições macroeconômicas não lhes sejam favoráveis. Com a conjunção alternativa "ou", cabe ao/à trabalhador "escolher" se deseja ser explorado/a, sem direitos, para que tenha um "emprego" que lhe gere seu mínimo sustento.

O que se percebe, portanto, é que os novos modelos de negócios geridos pelas grandes empresas, mormente as de capital financeiro e de tecnologia, estão reconfigurando o mundo do trabalho globalmente, com efeitos muito nefastos no Brasil, um país já profundamente desigual na distribuição de renda e no acesso às oportunidades, marcado por crises periódicas de desemprego e enorme informalidade. Eis um dos aspectos mais perversos da "uberização": o de tornar o trabalho cada vez mais precarizado, auto-gerenciável, com significativo aumento da jornada e diminuição dos ganhos reais de renda. Uma forma de trabalho com menor retorno, apesar de exigir mais deveres e menos direitos, sem contrapartida salarial fixa ou vinculação empregatícia, garantias asseguradas na Consolidação das Leis do Trabalho e na Constituição Federal. No Brasil, o discurso da "uberização", uma realidade cada vez mais concreta, parece ter encontrado seu representante ideal no atual dirigente da República.

\section{CONSIDERAÇÕES FINAIS}

A partir dos investimentos teóricos de Michel Pêcheux (2014), Eni Orlandi (2005) e Jean-Jacques Courtine (2016), o presente trabalho intentou mobilizar um gesto analítico e interpretativo acerca do discurso da "uberização" do trabalho. Para tanto, os conceitos de discurso, enquanto objeto teórico da Análise do Discurso, formação ideológica e formação discursiva precisaram ser igualmente mobilizados para uma fundamentação teórica do discurso em questão, bem como o papel do funcionamento do interdiscurso em sua atualização intradiscursiva e da memória, capaz de acionar saberes que procuram recuperar e estabilizar o empreendedorismo no mundo do trabalho como valor a ser perseguido, procurando silenciar, ao mesmo tempo, que, neste processo, a retirada de direitos acontece gradativa e vorazmente, especialmente com a perda de garantias asseguradas na Consolidação das Leis do Trabalho, a partir da "reforma trabalhista" de Michel Temer. Este intento prossegue, agora com o caos governamental que se instalou em Brasília. 
"Menos direitos e empregos ou todos os direitos e desemprego". Esta frase, epítome do que representa a "uberização", foi dita por Jair Bolsonaro quando interrogado sobre a crônica crise de desemprego que assola o Brasil, à época com 12 milhões de pessoas sem postos de trabalho formais, conforme indicava o IBGE - e que, aqui, tomamos como nossa sequência discursiva de referência (SDr). O Estado brasileiro, desde a crise econômica iniciada em 2014, demonstra-se inerte quanto à sua capacidade de melhorar a economia e a produção; ao revés, parece ter o Estado se revestido de outro papel além daquele que a Constituição Federal de 1988 o designava qual seja, o de proteger e cuidar dos cidadãos -, focando, agora, em retirar ou obstaculizar o acesso aos direitos, criando modalidades de trabalho que precarizam ainda mais o emprego do brasileiro médio, cujos ganhos salariais sempre estiveram aquém do esperado para se viver minimamente com dignidade. Com a "reforma" de 2017, contudo, direitos consagrados através de lutas e de duros processos políticos começam a desaparecer. Este projeto político, desalinhado com a necessidade popular e alinhado diretamente à dos grandes capitalistas - o empresariado industrial e do setor de serviços no Brasil -, tem sua continuidade assegurada pelo presidente de agora que, em sintonia com o zeitgeist do momento político brasileiro, ao nada propor para a economia e deixá-la entregue às empresas de capital financeiro internacional, resulta, também, no aumento do exército industrial de reserva a ser absorvido sem, contudo, terem estas empresas a obrigação de dar algum retorno aos trabalhadores com salários minimamente dignos, contratos, seguridade social e demais direitos que eram, até pouco tempo atrás, tidos como básicos dos trabalhadores brasileiros. Longe de ter visto seu esgotamento, o neoliberalismo se aprofunda, chancelado pelo Estado. Das empresas baseadas em tecnologia que sustentam essa nova dinâmica de reprodução das relações de produção, talvez a Uber seja um de seus nomes mais representativos. Precisando de um enorme contingente de trabalhadores/as precarizados/as em constante atividade para se manter no mercado e ampliar seus lucros, o capitalismo hodierno põe a questão da "uberização" como central na reconfiguração do mundo do trabalho, demonstrando-se como um processo mui alinhado, logo, com o mote presidencial aqui analisado.

\section{REFERÊNCIAS}

ABÍLIO, L. C. Sem maquiagem: o trabalho de um milhão de revendedoras de cosméticos. São Paulo: Boitempo, 2014.

AGÊNCIA de notícias CNI. Indústria brasileira é a $16^{\mathrm{a}}$ em participação na produção mundial do setor, aponta CNI. Disponível em: $<$ https://noticias.portaldaindustria.com.br/noticias/economia/industria-brasileira-e-a16a-em-participacao-na-producao-mundial-do-setor-aponta-cni/>. Acesso em: 03 nov. 2020.

ALTHUSSER, L. Ideologia e Aparelhos Ideológicos de Estado: notas para uma investigação. Rio de Janeiro: Edições Graal, 1985.

AMARAL, M. V. B. O avesso do discurso: análise de práticas discursivas no campo do trabalho. Maceió: EDUFAL, 2007.

ANTUNES, R. O privilégio da servidão: o novo proletariado de serviços na era digital. São Paulo: Boitempo, 2018.

COURTINE, J-J. Definição de orientações teóricas e construção de procedimentos em Análise do Discurso. In: Revista do Laboratório de Estudos do Discurso, Imagem e Som - LABEDIS / Museu Nacional / Universidade Federal do Rio de Janeiro. Rio de 
Janeiro: V. 1, n. 1, Jun. 2016, Semestral / Número de páginas 132 p. Tradução: Flávia Clemente de Souza; Márcio Lázaro Almeida da Silva.

FATOS e dados sobre a Uber. Disponível em: <https://www.uber.com/ptBR/newsroom/fatos-e-dados-sobre-uber/>. Acesso em: 15 set. 2020.

FILGUEIRAS, A. V. Dados de desemprego mostram que Reforma Trabalhista foi propaganda enganosa.

Disponível

em:

<https://blogdosakamoto.blogosfera.uol.com.br/uol_amp/2019/09/25/dados-de-

desemprego-mostram-que-reforma-trabalhista-foi-propaganda-enganosa/>. Acesso em: 25 set. 2020.

FILGUEIRAS, A. V.; KREIN, J. D.; OLIVEIRA, R. V. de. Reforma trabalhista no Brasil: promessas e realidade. Disponível em: <http://www.cesit.net.br/wpcontent/uploads/2019/09/Livro-REMIR-v-site.pdf>. Acesso em: 25 set. 2020.

IBGE - PNAD Contínua: taxa de desocupação é de $14,4 \%$ e taxa de subutilização é de $30,6 \%$ no trimestre encerrado em agosto de 2020. Disponível em: $<$ https://agenciadenoticias.ibge.gov.br/agencia-sala-de-imprensa/2013-agencia-denoticias/releases/29322-pnad-continua-taxa-de-desocupacao-e-de-14-4-e-taxa-desubutilizacao-e-de-30-6-no-trimestre-encerrado-em-agosto-de-2020>. Acesso em: 03 nov. 2020.

LE MONDE Diplomatique Brasil. Podcast Guilhotina. A uberização do trabalho: participação de Ludmila Chostek Abílio. Disponível em: <https://open.spotify.com/show/6dvrYjHmxjz9pqBzCk4Y81?si=FE3r_xZ-

QsGAoeDdqyLLhw>. Acesso em: 28 ago. 2020.

ᄀ﹎﹎. O trabalho no brasil: participação de Ricardo Antunes. Disponível em: <https://open.spotify.com/episode/3q1DI1frlXzrcUFy5UDHNa?si=uCx9IPNKRM1zdDuJ1Kzwg>. Acesso em: 30 ago. 2020.

Disponível

Bolsonaro, o ultraliberalismo e a crise do capital: participação de Leda Paulani.

<https://open.spotify.com/episode/3nhBeBUKpLRsEVNYDjcpsf?si= Voxm cOQqC7

ConlNX8ImA>. Acesso em: 02 set. 2020.

LEI No 5.452/1943. Disponível em: < http://www.planalto.gov.br/ccivil_03/DecretoLei/Del5452.htm>. Acesso em: 15 set. 2020.

LEI No 13.467/2017. Disponível em<http://www.planalto.gov.br/ccivil_03/_ato20152018/2017/lei/113467.htm> Acesso em: 15 set. 2020.

LIS, L. Pesquisa identifica quase 5 mil obras do PAC paralisadas no país. G1. Disponível em: < https://g1.globo.com/politica/noticia/2019/04/10/pesquisa-identificaquase-5-mil-obras-do-pac-paralisadas-no-pais.ghtml>. Acesso em: 03 nov. 2020.

MARX, K. Contribuição à crítica da economia política. São Paulo: Expressão Popular, 2008.

MARX, K.; ENGELS, F. Manifesto do Partido Comunista. São Paulo: Companhia das Letras, 2012.

MARTELLO, A. Nova Lei trabalhista deve gerar mais de 6 milhões de empregos, diz Meirelles. Disponível em: <https://g1.globo.com/economia/noticia/nova-lei-trabalhistavai-gerar-mais-de-6-milhoes-de-empregos-diz-meirelles.ghtml>. Acesso em: 15 set. 2020.

MOURA, F.; LIMA, M. S. Motoristas da Uber são trabalhadores independentes, decide STJ. Disponível em: <https://www.uol.com.br/tilt/noticias/bloomberg/2019/09/04/motoristas-da-uber-saotrabalhadores-independentes-decide-stj.htm>. Acesso em: 15 set. 2020. 
MOURÃO, H. Capitanias no Brasil. S.1., 28-29 set. 2019. Twitter: @GeneralMourao. Disponível em: <https://twitter.com/GeneralMourao/status/1178082467288403969>. Acesso em: 30 set. 2020.

NAGLE, L. Entrevista com Jair Bolsonaro. Sequência discursiva de referência aos 26'50". Disponível em: <https://www.youtube.com/watch?v=VLLxBxN87ZE >. Acesso em: 27 ago. 2020.

NETTO, J. P.; BRAZ, M. Economia política: uma introdução crítica. São Paulo: Cortez, 2012.

NISHIDA, E. Novo app Uber Works passa a oferecer vagas temporárias de empregos nos EUA. Disponível em: <https://gizmodo.uol.com.br/uber-works-vagastemporarias/>. Acesso em: 04 out. 2020.

PAMPLONA, N. Informalidade no país atinge 40 milhões, diz IBGE. Disponível em: $<$ https://www1.folha.uol.com.br/amp/mercado/2019/09/quase-40-milhoes-detrabalhadores-estao-na-informalidade-diz-ibge.shtml?_twitter_impression=true > Acesso em: 25 set. 2020.

ORLANDI, E. P. Análise de discurso: princípios e procedimentos. Campinas: Pontes, 2005.

PÊCHEUX, M. Semântica e discurso: uma crítica à afirmação do óbvio. Campinas: Editora da Unicamp, 2014.

Discurso: estrutura ou acontecimento. Campinas: Pontes, 2015.

OXFORD dicionário. "Empreendedorismo". Disponível em: <https://languages.oup.com/google-dictionary-pt/>. Acesso em: 03 nov. 2020.

PENHA, D. Em um ano, reforma trabalhista aumenta informalidade e enfraquece sindicatos. Repórter Brasil. Disponível em: < https://reporterbrasil.org.br/2018/11/emum-ano-reforma-trabalhista-aumenta-informalidade-enfraquece-sindicatos/ $>$. Acesso em: 03 nov. 2020.

REVISTA Exame. Bolsonaro: trabalhador que critica patrão devia empreender para ver como é. Disponível em: <https://exame.abril.com.br/brasil/e-tanto-direito-que-ospatroes-contratam-o-minimo-possivel-diz-bolsonaro/>. Acesso em: 27 ago. 2020.

SCHWARCZ, L. M.; STARLING, H. M. Brasil: uma biografia. São Paulo: Companhia das Letras, 2015.

SLEE, T. Uberização: a nova onda do trabalho precarizado. Tradução de João Peres. São Paulo: Editora Elefante, 2017.

UBER, Quem somos. Disponível em: <https://www.uber.com/br/pt-br/about/>. Acesso em: 04 nov. 2020.

Artigo recebido em: out. de 2020.

Aprovado e revisado em: jan. de 2021.

Publicado em: fev. de 2021.

Para citar este texto:

ALMEIDA, João Paulo Martins de. "Menos direitos e emprego ou todos os direitos e desemprego": A "uberização" do trabalho no Brasil no discurso presidencial. Entremeios [Revista de Estudos do Discurso, ISSN 2179-3514, on-line, www.entremeios.inf.br], Seção Estudos, Programa de Pós-Graduação em Ciências da Linguagem (PPGCL), Universidade do Vale do Sapucaí (UNIVÁS), Pouso Alegre (MG), vol. 23, p. 76-98, Edição especial/ 2020. DOI: http://dx.doi.org/10.20337/ISSN2179-3514revistaENTREMEIOSvol23pagina76a98 